\title{
Response of rotifer functional groups to changing trophic state and crustacean community
}

\author{
Ulrike OBERTEGGER* and Marina MANCA ${ }^{1)}$ \\ FEM - IASMA Research and Innovation Centre, Via E. Mach 2, I - 38010 S. Michele all'Adige (TN) \\ ${ }^{1)}$ CNR - Institute for Ecosystem Studies, Largo Tonolli 50, I - 28922 Verbania Pallanza (VB) \\ *e-mail corresponding author: ulrike.obertegger@iasma.it
}

\begin{abstract}
Information based on taxon-based indices is species-specific while information gained from function-based research can give a comprehensive view of ecosystem processes. We applied the guild-ratio, an index based on the proportion of functional groups of rotifers (i.e. microphagous and raptorial species), on a long-term data set of Lago Maggiore. By applying seasonal trend decomposition based on smoothing techniques and non-metrical multidimensional scaling, we assessed the response of rotifer functional groups to changes in trophic state and climate. While the taxon-based indices showed smooth changes, the function-based index showed a dramatic shift from a raptorial to a microphagous dominance, with a back-shift to raptorial dominance starting in 2000. The seasonal peak of microphagous and raptorial dry weight was clearly separated in the pre-eutrophication period. When mesotrophic conditions prevailed both peaks overlapped, only to be separated again with re-oligotrophication. We attributed these alterations of rotifer functional groups to changes in competition with crustacean zooplankton and to decreased phytoplankton algal abundance and size while altered seasonality in functional groups could be related to inter-group competition for food. We hypothesise that the effects of trophic state (i.e. altered phytoplankton) and climate (i.e. altered cladoceran community) were transferred across trophic levels to rotifer functional groups. Our study highlights that functional groups are valid instruments for illustrating unifying principles in ecology through a better understanding of ecosystem processes and the interrelationship between trophic levels.
\end{abstract}

Key words: microphagous rotifers, raptorial rotifers, STL, Daphnia, diversity, phytoplankton

\section{INTRODUCTION}

The aim of community ecology is to find general rules that govern plant and animal communities. Traditionally, researcher focus on species identity; however, recently the focus has shifted to species traits (Díaz \& Cabido 2001; Reynolds et al. 2002; Simberloff 2004). Traits are tied to species' functions in the ecosystem, and a trait-based research offers the advantage of providing a mechanistic view of community functioning; this is an important prerequisite to better understand and predict issues driven by global change (McGill et al. 2006; Moss et al. 2009).

In Lago Maggiore, a deep subalpine lake, the impact of global change on different processes and biological components of the plankton community has been extensively investigated. Since the 80 s, increased water temperatures and an earlier onset of thermal stratification were detected as a consequence of global warming (Ambrosetti \& Barbanti 1999; Manca et al. 2007a). These changes in stratification regime resulted in longterm effects, such as altered seasonality of zooplankton and predator-prey timing (Manca \& DeMott 2010). Specifically, the earlier onset and longer duration of stratification was related to an increase in abundance of the predator Bythotrephes longimanus (Manca et al. $2007 \mathrm{a}, \mathrm{b}$ ), leading to a sharp decrease in crustacean zooplankton biomass (Manca 2011) and changes in the seasonality of the large filter feeder Daphnia gr. hyalinagaleata (Visconti et al. 2008). Also, short-term effects of climate change, such as exceptionally high levels of abundance and biomass and a community structure resembling those of the eutrophication phase, have been observed during very warm periods (i.e. spring and summer of 2003) (Visconti et al. 2008). Apart from this detailed view on certain physical processes and biological interactions of species in relation to climate change, a traitbased approach has not yet been applied in this lake.

For phytoplankton, trait-based approaches are already well developed and identify algal suitability for zooplankton grazing and characterize lake trophic level (see Reynolds et al. 2002). However, little has been done for zooplankton (Barnett et al. 2007; Barnett \& Beisner 2007) and especially for rotifers (Rotifera Monogononta). In lakes, rotifers often dominate zooplankton abundance and taxa (e.g., Orcutt \& Pace 1984; Obertegger et al. 2007) and are an important component of the aquatic food web (Miracle et al. 2007). Furthermore, monogonont rotifers are very sensitive to environmental stress, responding to pollution (Sládeček 1983), changes in trophic state (Berzins \& Pejler 1989a), predation pressure (Williamson 1987), and climate (Epp et al. 2010). These characteristics make rotifers excellent targets for ecological studies.

Recently, Obertegger et al. (2011) proposed a modification of the original Guild Ratio (GR; Smith et al. 


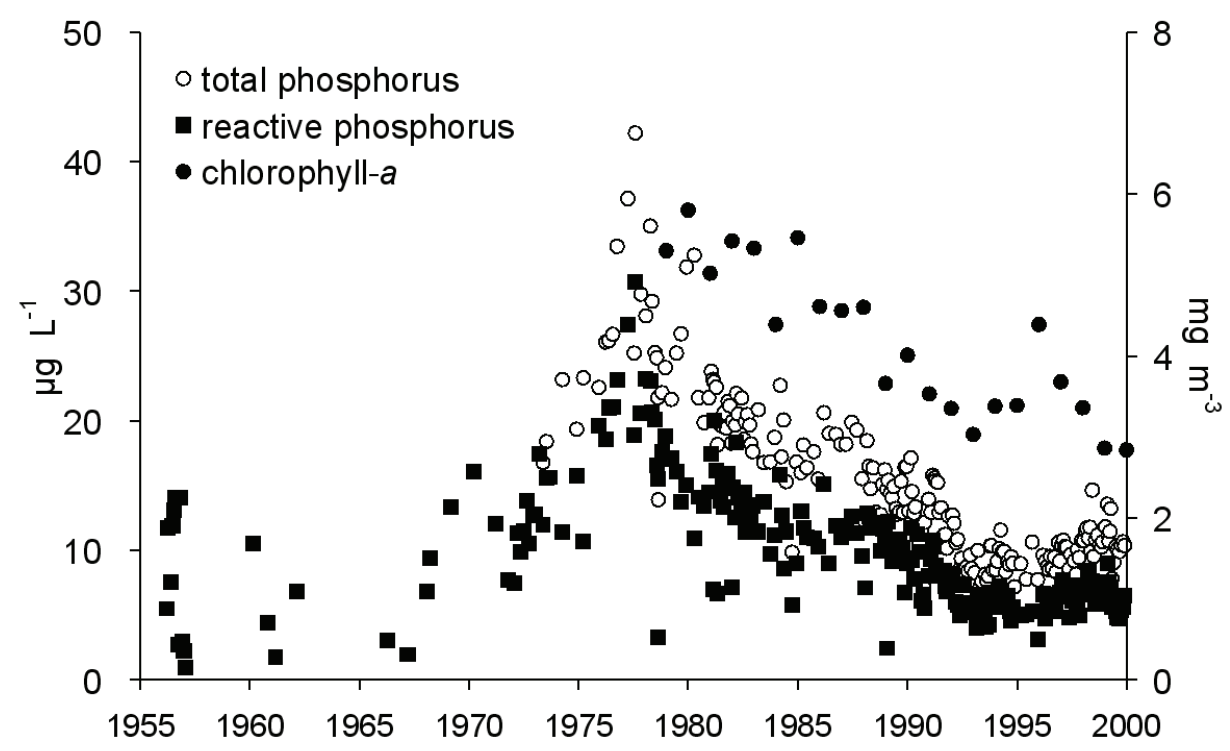

Fig. 1. Phosphorus (left axis) and mean annual chlorophyll- $a$ (right axis) concentrations in the epilimnion of Lago Maggiore before, during and after eutrophication (data kindly provided by A. Calderoni and G. Morabito).

2009), where planktonic rotifers are grouped into microphagous and raptorial species, based on food acquisition and processing, in order to assess the dominance of these two functional groups. The GR is calculated in the following way: GR = (biomass raptorial biomass microphagous)/(total rotifer biomass), and values range from -1 to +1 ; values $>0$ indicate microphagous dominance while values $<0$ indicate raptorial dominance. The GR permits integrating taxon-based classic approaches with an insight of their relation with the environment and ecosystem processes (Obertegger et al. 2011).

Worldwide efforts have been made to restore former conditions in polluted and eutrophic lakes (Anderson et al. 2005). Lago Maggiore has also undergone re-oligotrophication based primarily on nutrient reduction. We applied the GR to a long-term data set with the aim of understanding the response of the rotifer community to changes in trophic state. We expected that i) changes in trophic state were better reflected by functional groups and the GR than by taxon-based measures of biodiversity, and ii) functional groups, GR, and other parameters presently found are not the same as those of the original oligotrophic state. Specifically, we expected changes in dry weight, diversity (number of taxa, evenness, GR), and seasonality of microphagous and raptorial rotifers along with changes in trophic state. Given the impact of climate change on Lago Maggiore, we also tried to understand iii) to what extent changes in the planktonic rotifer community were attributable to recent warming.

\section{MATERIALS AND METHODS}

\subsection{Study site}

Lago Maggiore, the second largest $\left(212.5 \mathrm{~km}^{2}\right)$ and deepest (maximum depth $370 \mathrm{~m}$, mean depth $171 \mathrm{~m}$ ) subalpine lake (194 m above sea level), lies on a long $(54 \mathrm{~km})$ and narrow (mean breadth $2.94 \mathrm{~km}$ ) basin on the border between Italy and Switzerland. The lake experiences cool summers and warm winters and does not freeze. Phosphorus-limited and oligotrophic, the lake underwent a continuous increase in total phosphorus (TP) by the end of the 1960s through the seventies, reaching meso-eutrophic conditions, as a consequence of increased human impact (Fig. 1). A slow reversal from eutrophication, due to the gradual implementation of sewage treatment plants and the reduction of the phosphorus content in detergents in the 1980s, has been documented in a long series of papers and technical reports (e.g., de Bernardi et al. 1990; Manca et al. 2007b). During re-oligotrophication, TP concentrations (measured at winter mixing) decreased from $19 \mu \mathrm{g} \mathrm{L}^{-1}$ to $c a 13 \mu \mathrm{g} \mathrm{L}^{-1}$ in the late $1980 \mathrm{~s}$, approaching a value of $8 \mu \mathrm{g} \mathrm{L}^{-1}$ in the mid 1990s. Current values are $c a 10 \mu \mathrm{g}$ $\mathrm{L}^{-1}$. Chlorophyll- $a$ concentration (chl- $a$, mean annual value) also decreased, more sharply in the first half of the $1990 \mathrm{~s}$, from ca $5 \mathrm{mg} \mathrm{m}^{-3}$ to $c a 3 \mathrm{mg} \mathrm{m}^{-3}$ (Manca \& Ruggiu 1998).

\subsection{Sampling}

Sampling was monthly for the period 1948 to 2002 . Protocols of data collection are explained in Manca et al. (2007a, 2009). Briefly, rotifer samples were taken with a $76 \mu \mathrm{m}$ nylon net. Chick et al. (2010) show that rotifer sampling with nets $>20 \mu \mathrm{m}$ underestimates rotifer abundance. However, the same net was used throughout the study allowing a valid comparison between years. Species identification followed standard keys (Ruttner-Kolisko 1974; Koste 1978; Braioni \& Gelmini 1983). Estimates of rotifer biomass were made by applying the biovolume equations of Ruttner-Kolisko 
(1977) to direct measurements and mid-range size estimates as reported by Koste (1978). Rotifer dry weight (RDW) was estimated according to Bottrell et al. (1976).

\subsection{Data analysis}

Rotifers were classified into feeding guilds, and the guild ratio for biomass (GR) was calculated according to Obertegger et al. (2010). We applied locally weighted regression smoothing (LOESS) on the whole data set of species richness $(\mathrm{N})$, rotifer dry weight (RDW), evenness (E) (Pielou 1966) and GR. LOESS allows interpolation between sampling gaps to give a graphical representation of trends but does not provide statistical tests. We used different span widths compromising between smoothness and adaptation to the data. Furthermore, we applied non-metrical multidimensional scaling (NMDS) on square root transformed RDW data. The statistical technique of NMDS uses only rank information of samples based on community dissimilarity and can handle non-linear species responses of any shape. In NMDS, we selected those periods that did not have major sampling gaps and were related to different trophic phases of the lake. The period 1948-1950 was considered the pre-eutrophication period (OLIGO1); the period 19811992 was related to changes in trophic state (eutrophication and slow re-oligotrophication; MESO-OLIGO), and the period 1995-2002 was related to a new, stable, oligotrophic condition (OLIGO2). The years after 2002 were not included as 2003 summer was exceptionally warm (the warmest of the last 2 centuries; Jankowski et al. 2006; Visconti et al. 2007).

We, furthermore, applied seasonal trend decomposition based on locally weighted regression (STL; Cleveland et al. 1990) to the three periods. In STL, we used absolute values of E and RDW and logarithmically transformed DW of raptorials and microphagous rotifers to extract the seasonal pattern. STL is an iterative nonparametric procedure used to extract both the trend and the seasonal pattern. In detail, a time series can be modelled as the sum of three components: a low-frequency long-term component, a high-frequency seasonal component, and a residual component. The STL uses a continuous LOESS-line for the trend and specific LOESSlines for the monthly subseries to estimate the seasonal component. Fitting is done iteratively until the resulting components stabilise. Parameter determination was done as recommended by Cleveland et al. (1990). All analyses were performed in R 2.9.1, package stats 2.9.1 and vegan 1.15-3 (R Development Core Team 2009).

\section{RESULTS}

We applied a span width of 0.4 for LOESS smoothing of species richness $(\mathrm{N})$, rotifer dry weight (RDW), and guild ratio (GR) while for evenness (E) we used 0.75. Mean N was six during OLIGO1 (1948 to 1950), ranging from a minimum of 2 to a maximum of 9 (Fig. 2A). From September 1957 to September 1958, N showed exceptionally high values (minimum $=13$, maximum $=$ 19 taxa). From 1962 onwards, N increased with values oscillating between 4 and 21 taxa in MESO-OLIGO (1981 to 1992) and between 4 and 20 taxa in OLIGO2 (1995 to 2002). RDW was lower than $10 \mathrm{mg} \times \mathrm{m}^{-3}$ until the middle 1980s; exceptions were observed in December 1957, May 1976, and July 1979. After 1992, RDW sharply increased to a mean annual value of $17 \mathrm{mg} \mathrm{m}^{-3}$ in 2002 (Fig. 2B). E was low during OLIGO1, on average close to 0.2 with maxima of $0.4-0.5$; values more than doubled (0.4-0.5) in the middle seventies, remained almost constant between 1980 and 1984, and decreased only slightly during OLIGO2 (Fig. 2C).

The GR remained stable with a marked raptorial dominance until 1986, after which the community shifted towards microphagous taxa. The latter became largely dominant after 1992, but a return to raptorial dominance was evident after 1999 (Fig. 3).
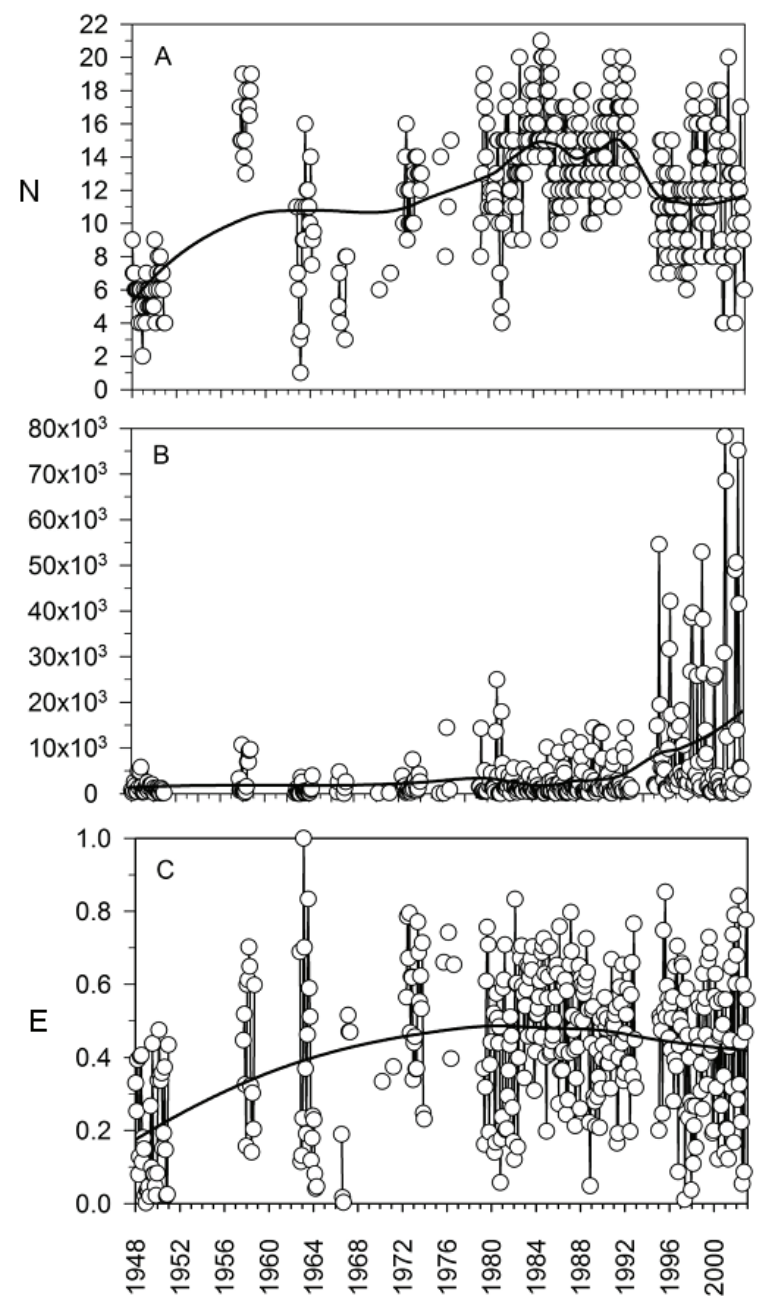

Fig. 2. A: LOESS smoothing of species richness $(\mathrm{N}$; span width $=0.4)$. B: LOESS smoothing of rotifer dry weight $($ RDW; span with $=0.4)$. C: LOESS smoothing of evenness $(\mathrm{E}$; span width $=0.75)$. 


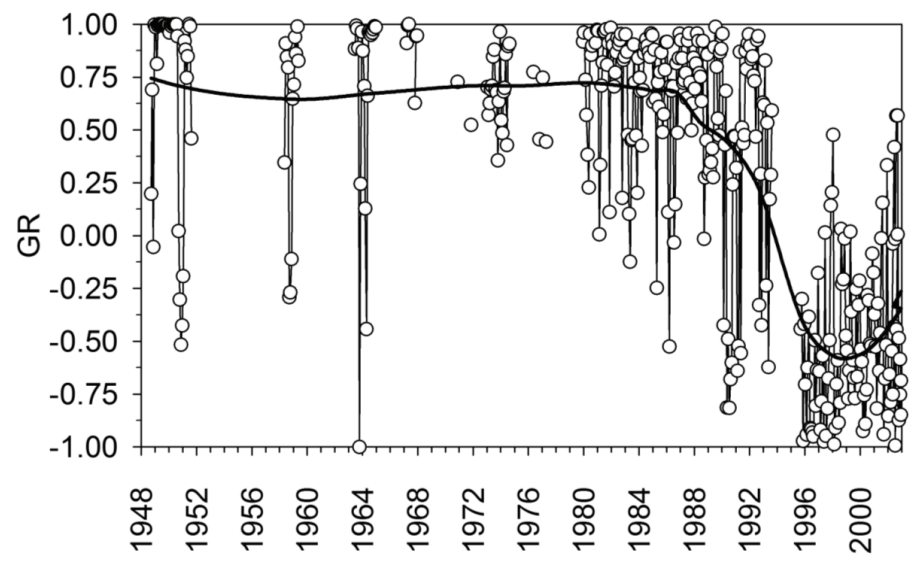

Fig. 3. LOESS smoothing of the guild ratio $(\mathrm{GR}$; span width $=0.4)$.

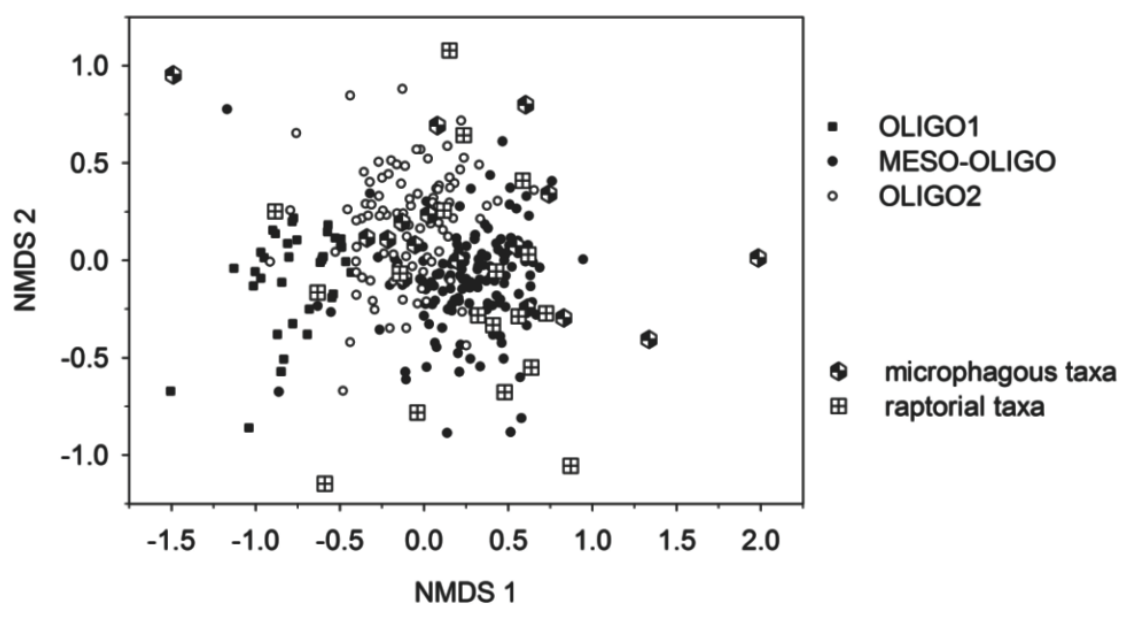

Fig. 4. NMDS on square root-transformed RDW data. OLIGO1 (1948-1950); MESO-OLIGO (1981-1992); OLIGO2 (1995-2002).
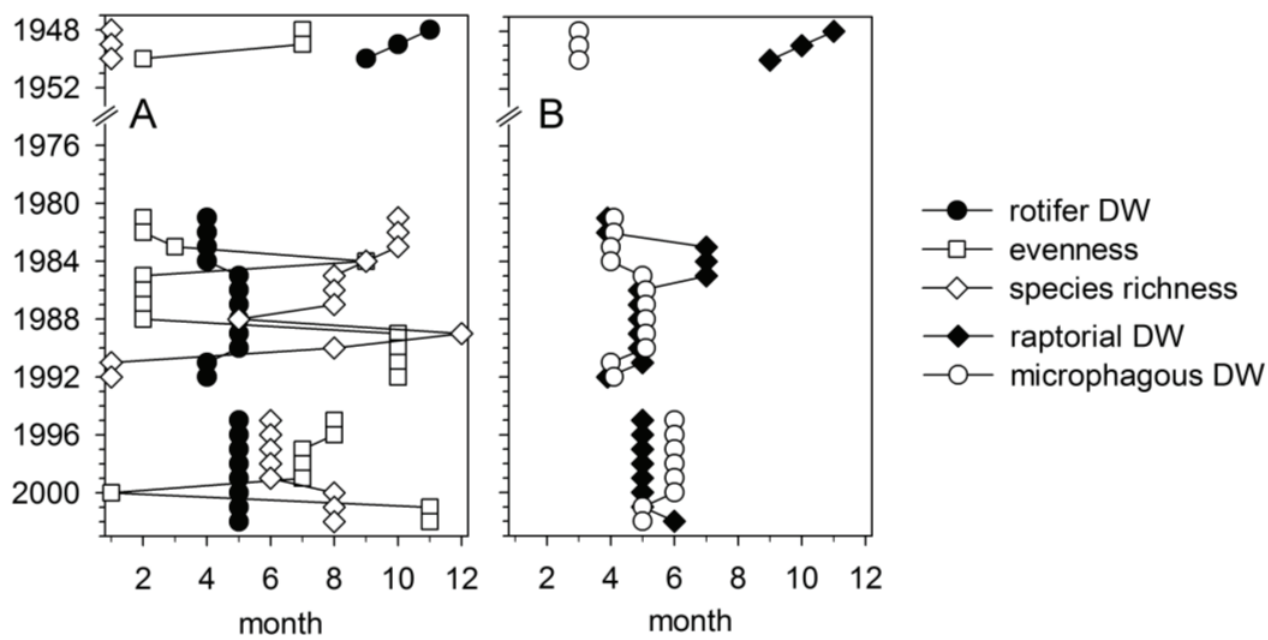

Fig. 5. Seasonality for the first maximum value as extracted by STL. The period 1948-1950 refers to OLIGO1, 1981-1992 to MESOOLIGO, and 1995-2002 to OLIGO2; therefore, symbols only within periods are connected by a line. A: taxon-based metrics; B: functional classification of rotifers. Please note the interruption of the y-axis. Dry weight is DW. 
NMDS on RDW showed three groups which corresponded to the three periods of change in trophic state (Fig. 4). The OLIGO2 period was dominated by microphagous taxa while the OLIGO1 and the MESO-OLIGO period were dominated by raptorial taxa. Specifically, during OLIGO1 and MESO-OLIGO, the raptorials $A s-$ planchna priodonta, Ploesoma truncatum, Synchaeta pectinata, $S$. gr. tremula-oblonga, and Trichocerca rousseleti dominated, respectively, while during OLIGO2 the microphagous rotifers C. unicornis-hippocrepis gr. (Ruttner-Kolisko 1974), Kellicottia longispina, Filinia terminalis, Notholca labis, and Keratella quadrata and the raptorials Polyarthra spp. and Ascomorpha ovalis dominated.

Seasonality of the maxima of N, RDW, E and DW of the microphagous and raptorial taxa showed altered timing for the different periods (Fig. 5). For N, the maximum shifted from winter (OLIGO1) to summer/early autumn (OLIGO2); during MESO-OLIGO, maximum shifted from October (1981) to January (1992) with several maxima during the years 19851989. For RDW, the maximum shifted from autumn to spring. Seasonality of maximum E showed no clear pattern (Fig. 5A). During OLIGO1, microphagous rotifers had their maximum quite earlier than raptorials, while during MESO-OLIGO, the two often overlapped with the exception of 1983-1985 and 1992 (Fig. 5B). During MESO-OLIGO, the maximum of microphagous rotifers shifted from March to April and back to March. However, the maximum of raptorial rotifers showed an alternation from March to July and May. During OLIGO2, microphagous and raptorial rotifers were close but again separated, with DW maxima of raptorial taxa in June, one month later than those of microphagous taxa; the only exception was during year 2001, when they both peaked in May.

According to the overlap of indices, during OLIGO1 the maximum of RDW most strikingly corresponded to microphagous DW, while during MESO-OLIGO the maximum of DW was equivalent for both functional groups. During OLIGO2, the RDW maximum corresponded to microphagous DW. In the last two years considered, however, RDW corresponded to microphagous DW.

\section{DISCUSSION}

Except for the relation of Conochilus colony size to Daphnia predation pressure and food uptake (Manca \& Sonvico 1996), little is known about how trophic state and climate warming affect rotifers in Lago Maggiore. Our study demonstrated that functional groups of rotifers show a distinct response to changes in trophic state. While phosphorus and chlorophyll- $a$ concentrations indicate a return to pre-eutrophication conditions (de Bernardi et al. 1990; Manca \& Ruggiu 1998; Ruggiu et al. 1998), the transitions from an oligotrophic to a mesotrophic and back to an oligotrophic state left their fingerprints on the rotiferan community. The per- ception of the extent of changes on the rotiferan community, however, depended on the metrics used.

While taxon-related metrics (i.e., species richness, rotifer dry weight, and evenness) indicated smooth changes, the guild ratio indicated that the rotifer community underwent a dramatic shift from a raptorial feeding mode to a microphagous mode concurrently with other important changes in crustacean zooplankton after lake restoration processes (Manca \& Ruggiu 1998). Intriguingly, eutrophication did not change the functional structure of planktonic rotifers in Lago Maggiore, which remained strongly characterized by a dominance of raptorial taxa. However, raptorial dominance declined after 1988 concomitantly with changes in cladocerans: Bythotrephes longimanus increased by an order of magnitude, Daphnia gr. hyalina-galeata showed a sharp decline and small cladocerans such as Eubosmina longispina and Diaphanosoma brachyurum increased (Manca \& Ruggiu 1998; Manca \& DeMott 2009; Manca 2011). An increase in B. longimanus releases rotifers, especially large $C$. hippocrepis colonies, from competition with cladocerans (Hovius et al. 2006; Manca 2011). In Lago Maggiore, abundance and mean size of phytoplankton cells decreases with restoration (Manca \& Ruggiu 1998; Kamenir \& Morabito 2009). While microphagous species ingest multiple food items no larger than $\sim 15-20 \mu \mathrm{m}$, raptorials prefer larger particles (Pourriot 1977; Karabin 1985; Wallace et al. 1989). Therefore, we suggest that microphagous species were enhanced by decreased abundance of competitors and decreased food size, while raptorial species were able to coexist with their competitors. This interpretation is also corroborated by Obertegger et al. (2010) that show that raptorials or microphagous species dominate when cladocerans increase or decrease, respectively. It seems that this is a general principle because it applies to three different lakes (this study and Lake Washington and Lake Caldonazzo in Obertegger et al. 2011).

Raptorial species were generally larger than microphagous ones (mean $=0.75 \times 10^{-3} \mathrm{~mm}^{3}$ vs $0.39 \times 10^{-3} \mathrm{~mm}^{3}$ individual volume). Therefore, the transition towards dominance of microphagous taxa also saw a shift towards a smaller mean body size. In rotifers, body size is positively correlated with food threshold level (Stemberger \& Gilbert 1987). This may additionally explain why smaller microphagous species could coexist with small cladoceran competitors for smaller algal particles. Specifically, large $(\geq 1 \mathrm{~mm}$ diameter $)$ Conochilus colonies have feeding rates comparable to Daphnia and lead to a seasonal increase in water clarity similar to that caused by Daphnia grazing (Manca \& Sonvico 1996). We additionally suggest that colonies of the microphagous Conochilus substituted Daphnia as a major algal grazer. However, only laboratory or mesocosms' experiments could clarify this issue.

Surprisingly, toward the beginning of the new millennium, dominance of microphagous rotifers seemed to 
weaken. This recovery of raptorials was related to increased abundance of Polyarthra spp. and Ascomorpha ovalis. After 2000, abundance of Daphnia and of Leptodora kindtii also increased as a result of their altered seasonal dynamics after Lago Maggiore's warming (Manca 2011). Mean water temperatures in the upper $20 \mathrm{~m}$ increased by $3{ }^{\circ} \mathrm{C}$ during the period 1983 2002 (Manca \& DeMott 2009). Rotifers are eurythermal, cold, or warm stenothermal species; however, Berzins \& Pejler (1989b) show in their exhaustive study that rotifer species tolerate a wide range of temperatures. Higher temperatures can offer a demographic advantage for certain rotifer species (Williamson et al. 1996; Armengol \& Miracle 2000) and can increase ingestion rate (Stelzer 2006). However, the effect of temperature on rotifers also depends on food resources with the combination of high temperature and high food resources having a positive effect (Oltra \& Todoli 1997). Because temperature effects seem to be speciesspecific and not attributable to rotifer guilds (i.e., raptorials and microphagous rotifers), we suggest that the rupture of absolute microphagous dominance is not related to a temperature increase but to the re-establishment of exploitative competition between Daphnia and microphagous rotifers. Interference competition between Daphnia and rotifers also leads to suppression of rotifers (Stemberger \& Gilbert 1985). Smaller microphagous rotifers might especially be vulnerable to this kind of stress. Therefore, competition with Daphnia (exploitative and/or interference) seems to result in an increase in raptorial rotifers promoting species that are also able to ingest small algae. Both, Polyarthra and Ascomorpha have a virgate trophus type and this characteristic could concomitantly with other undefined factors (e.g., demographic differences, predation, interspecies competition, and diseases) favour these species above other raptorials. We, furthermore, hypothesise that the process of shifting dominance structure might not be finished, and we cannot exclude the possibility that raptorial rotifers will again dominate in the lake with maxima as observed in the 50s. This seems plausible considering, i) low TP values, and ii) the recovery of Daphnia. The most recent period, however, is not entirely comparable to OLIGO1 (1948 to 1950) because of far higher levels of abundance of predatory cladocerans (Manca 2011).

Generally, rotifers show a marked spring peak and a smaller autumn peak under eutrophic conditions, while a single peak characterizes oligotrophic conditions (Sommer et al. 1986). This concept, however, does not take into account feeding traits of rotifers. During OLIGO1 raptorials and microphagous rotifers were markedly separated; during OLIGO-MESO (1981 to 1992) and OLIGO2 (1995 to 2002) they were close together. These transitions could be related to varying algal food quality and quantity in Lago Maggiore as reported by Manca \& Ruggiu (1998) and Kamenir \&
Morabito (2009). The presence of high quality food might attenuate exploitative competition between guilds resulting in overlapping peaks, while decreasing food resources might lead to alternated biomass peaks.

Species composition during the two periods of similar trophic state was different, furthermore indicating that from a biological point of view OLIGO1 and OLIGO2 were not the same. While it is difficult to understand why specific species characterised certain periods, the trait-based view helped to find a unifying view.

This study underlines that a successful restoration and a return to the original oligotrophy did not result in a return to the same plankton rotifers' community and dominance of functional groups. The different biological components of the ecosystem reacted with different time delays. While we cannot exclude that the biological system will be able to return to pre-eutrophication conditions, as suggested by cladocera subfossil remains (Manca et al. 2007b), we certainly can state that the return is not as prompt and straightforward as for nutrient reduction. The observed shifts of functional groups of planktonic rotifers may be fully justified by the observed changes in crustacean zooplankton and in phytoplankton algal cells abundance and size.

\section{ACKNOWLEDGEMENTS}

The present study was based on pluri-annual data collected in the framework of the Lago Maggiore monitoring program funded by the Swiss-Italian Commission for the Protection of Lago Maggiore waters. Data from the years 1948-1950 were taken from Baldi et al. (1953) and Tonolli (1962). This work was carried out within the research activity funded by FEMIASMA. We thank W.R. DeMott and an anonymous reviewer for critical comments and suggestions on an earlier version of the manuscript. We thank G. Flaim for linguistic improvements.

\section{REFERENCES}

Anderson, N.J., E. Jeppesen \& M. Sondergaard. 2005. Ecological effects of reduced nutrient loading (oligotrophication) on lakes: an introduction. Freshwat. Biol., 50: 15891593.

Ambrosetti, W. \& L. Barbanti. 1999. Deep water warming in lakes: an indicator of climatic change. J. Limnol., 58: 1-9.

Armengol, X. \& M.R. Miracle. 2000. Diel vertical movement of zooplankton in Lake La Cruz (Cuenca, Spain). J. Plankton Res., 22: 1683-1703.

Baldi, E., V. Tonolli \& L. Tonolli Pirocchi. 1953. La differente evoluzione di due laghi già costituenti un unico bacino: il Lago Maggiore e il Lago di Mergozzo. Mem. Ist. ital. Idrobiol., 7: 49-107.

Barnett, A. \& B.E. Beisner. 2007. Zooplankton biodiversity and lake trophic state: explanations invoking resource abundance and distribution. Ecology, 88: 1675-1686.

Barnett, A.J., K. Finlay \& B. Beisner. 2007. Functional diversity of crustacean zooplankton communities: towards a traitbased classification. Freshwat. Biol., 52: 796-813. 
Berzins, B. \& B. Pejler. 1989a. Rotifer occurrence and trophic degree. Hydrobiologia, 182: 171-180.

Berzins, B. \& B. Pejler. 1989b. Rotifer occurrence in relation to temperature. Hydrobiologia, 175: 223-231.

Braioni, M.G. \& D. Gelmini. 1983. Rotiferi Monogononti (Rotatoria: Monogononta). In: Guide per il riconoscimento delle specie animali delle acque interne italiane, vol. 23. Consiglio Nazionale delle Ricerche, Roma: 180 pp.

Bottrell, H.H., A. Duncan, Z.M. Gliwicz, E. Grygierek, A. Herzig, A. Hillbricht-Nicowska, H. Kurosawa, P. Larsson \& T.A Weglenska. 1976. A review of some problems in zooplankton production studies. Norwegian Journal of Zoology, 24: 419-456.

Cleveland, R.B., W.S. Cleveland, J.E. McRae \& I. Terpenning. 1990. STL: a seasonal-trend decomposition procedure based on Loess. Journal of Official Statistics, 6: 3-73.

Chick, J.H., A.P. Levchuk, K.A. Medley \& J.H. Havel. 2010. Underestimation of rotifer abundance, a much greater problem than previously appreciated. Limnol. Oceanogr. Methods, 8: 79-87.

de Bernardi, R., G. Giussani, M. Manca \& D. Ruggiu. 1990. Trophic status and the pelagic system of Lago Maggiore. Hydrobiologia, 191: 1-8.

Díaz, S. \& M. Cabido. 2001. Vive la différence: plant functional diversity matters to ecosystem processes. Tends Ecol. Evol., 16: 646-655.

Epp, L.S., K.R. Stoof, M.H. Trauth \& R.Tiedemann. 2010. Historical genetics on a sediment core from a kenyan lake: intraspecific genotype turnover in a tropical rotifer is related to past environmental changes. J. Paleolimnol., 43: 939-954.

Hovius, J.T., B.E. Beisner \& K.S. McCann. 2006. Epilimnetic rotifer community responses to Bythotrephes longimanus invasion in Canadian Shield lakes. Limnol. Oceanogr., 51: 1004-1012.

Jankowski, T., D.M. Livingstone, H. Bührer, R. Forster \& P. Niederhauser. 2006. Consequences of the 2003 European heat wave for lake temperature profiles, thermal stability, and hypolimnetic oxygen depletion: Implications for a warmer world. Limnol. Oceanogr., 51: 815-819.

Kamenir, Y. \& G. Morabito. 2009. Lago Maggiore oligotrophication as seen from the long-term evolution of its phytoplankton taxonomic size structure. J. Limnol., 68: 146-161.

Karabin, A. 1985. Pelagic zooplankton (Rotatoria and Crustacea) variation in the process of lake eutrophication. II. Modifying effect of biotic agents. Ekologia Polska, 33: 617-644.

Koste, W. 1978. Rotatoria. Die Rädertiere Mitteleuropas. 2 vols. Gebrüder Borntraeger, Berlin, Stuttgart: 673 pp.

Manca, M., M. Portogallo \& M.E. Brown. 2007a. Shifts in phenology of Bythotrephes longimanus and its modern success in Lago Maggiore as a result of changes in climate and trophy. J. Plankton Res., 29: 515-525.

Manca, M., B. Torretta, P. Comoli, S.L. Amsinck \& E. Jeppensen. 2007b. Major changes in trophic dynamics in large, deep subalpine Lago Maggiore from 1940s to 2002: a high resolution comparative paleo-neolimnological study. Freshwat. Biol., 52: 2256-2269.

Manca, M. \& W.R. DeMott. 2009. Response of the invertebrate predator Bythotrephes to a climate-linked increase in the duration of a refuge from fish predation. Limnol. Oceanogr., 54: 2506-2512.

Manca, M. \& D. Ruggiu. 1998. Consequences of pelagic foodweb changes during a long-term lake oligotrophication process. Limnol. Oceanogr., 43: 1368-1373.

Manca, M. \& D. Sovinco. 1996. Seasonal variations in density an population size structure of Conochilus in Lago Maggiore: a biannual study. Mem. Ist. ital. Idrobiol., 54: 97-108.

Miracle, M.R., M.T. Alfonso \& E. Vicente. 2007. Fish and nutrient enrichment effects on rotifers in a Mediterranean shallow lake: a mesocosm experiment. Hydrobiologia, 593: 77-94.

McGill, B.J., B.J. Enquist, E. Weiher \& M. Westoby. 2006. Rebuilding community ecology from functional traits. Tends Ecol. Evol., 21: 178-185.

Moss, B., D. Hering, A.J. Green, A. Aidoud, E. Becares, M. Beklioglu, H. Bennion, D. Boix, S. Brucet, L. Carvalho, B. Clement, T. Davidson, S. Declerck, M. Dobson, E. van Donk, B. Dudley, H. Feuchtmayr, N. Friberg, G. Grenouillet, H. Hillebrand, A. Hobaek, K. Irvine, E. Jeppesen, R. Johnson, I. Jones, M. Kernan, T. L. Lauridsen, M. Manca, M. Meerhoff, J. Olafsson, S. Ormerod, E. Papastergiadou, W.E. Penning, R. Ptacnik, X. Quintana, L. Sandin, M. Seferlis, G. Simpson, C. Trigal, P. Verdonschot, A.M. Verschoor \& G.A. Weyhenmeyer. 2009. Climate change and the future of freshwater biodiversity in Europe: a primer for policy-makers. Freshwater Reviews, 2: 103-130.

Obertegger, U., H.A. Smith, G. Flaim \& R.L. Wallace. 2011. Using the guild ratio to characterize pelagic rotifer communities. Hydrobiologia, 662:157-162.

Obertegger, U., G. Flaim, M.G. Braioni, R. Sommaruga, F. Corradini \& A. Borsato. 2007. Water residence time as a driving force of zooplankton structure and succession. Aquat. Sci., 69: 575-583.

Orcutt, J.D. \& M.L. Pace. 1984. Seasonal dynamics of rotifer and crustacean zooplankton populations in a eutrophic, monomictic lake with a note on rotifer sampling techniques. Hydrobiologia, 119: 73-80.

Oltra, R. \& R. Todolì. 1997. Effects of temperature, salinity and food level on the life history traits of the marine rotifer Synchaeta cecilia valenrina, n. subsp. J. Plankton Res., 19: 693-702.

Pielou, E.C. 1966. The measurement of diversity in different types of biological collection. J. Theor. Biol., 13: 131-144.

Pourriot, R. 1977. Food and feeding habits of Rotifera. Archiv. Hydrobiol. Beih. Ergebn. Limnol., 8: 243-260.

Reynolds, C.S., V. Huszar, C. Kruk, L. Naselli-Flores, \& S. Melo. 2002. Towards a functional classification of the freshwater phytoplankton. J. Plankton Res., 24: 417-428.

Ruggiu, D., G. Morabito, P. Panzani \& A. Pugnetti. 1998. Trends and relations among basic phytoplankton characteristics in the course of the long-term oligotrophication of Lago Maggiore (Italy). Hydrobiologia, 369/370: 243-257.

Ruttner-Kolisko, A. 1974. Plankton rotifers, biology and taxonomy. In: Das Zooplankton der Binnengewässer, Suppl.Edition. English transl. of chapter "Rotatoria". Die Binnengewässer, 26(1): $146 \mathrm{pp}$.

Ruttner-Kolisko, A. 1977. Suggestions for biomass calculations of planktonic rotifers. Arch. Hydrobiol., 8: 71-76.

R Development Core Team. 2009. R: a language and environment for statistical computing. R Foundation for Statistical Computing, Vienna. (Available at: http://www.rproject.org).

Simberloff, D. 2004. Community ecology: is it time to move on? Am. Nat., 163: 787-799.

Sládeček, V. 1983. Rotifers as indicators of water-quality. Hydrobiologia, 100: 169-201.

Smith, H.A., J. Ejsmont-Karabin, T.M. Hess \& R.L. Wallace. 2009. Paradox of planktonic rotifers: similar structure but unique trajectories in communities of the Great Masurian Lakes, (Poland). Verh. Internat. Verein. Limnol., 30: 951-956.

Sommer, U., Z.M. Gliwicz, W. Lampert, A. Duncan. 1986. PEG-model of seasonal succession of planktonic events in fresh waters. Arch. Hydrobiol., 106: 433-471.

Stelzer, C.P. 2006. Competition between two planktonic rotifer species at different temperatures: an experimental test. Freshwat. Biol., 51: 2187-2199.

Sternberger, R.S. \& J.J. Gilbert. 1985. Body size, food concentration and population growth in planktonic rotifers. Ecology, 66: 1151-1159. 
Stemberger, R.S. \& J.J. Gilbert. 1987. Rotifer threshold food concentrations and the size-efficiency hypothesis. Ecology, 68: 181-187.

Tonolli, V. 1962. L'attuale situazione del popolamento planctonico del Lago Maggiore. Mem. Ist. ital. Idrobiol., 15: 81-134

Visconti, A., M. Manca \& R. de Bernardi. 2008. Eutrophication-like response to climate warming: an analysis of Lago Maggiore (N. Italy) zooplankton in contrasting years $J$. Limnol., 67: 87-92.

Wallace, R.L., T.W. Snell, C. Ricci \& T. Nogrady. 2006. Rotifera volume 1: Biology, Ecology and Systematics. $\left(2^{\text {nd }}\right.$ ed.) In: H.J.F. Dumont (Ed.), Guides to the Identification of the Microinvertebrates of the Continental Waters of the World, vol. 23. Kenobi Productions, Ghent, and Backhuys Publishers, Leiden: 299 pp.

Williamson, C.E., R.W. Sanders, R.E. Moeller, \& P.L. Stutzman. 1996. Utilization of subsurface food resources for zooplankton reproduction: Implication for diel vertical migration theory. Limnol. Oceanogr., 41: 224-233.

Williamson, C.E. 1987. Predator-prey interactions between omnivorous diaptomid copepods and rotifers: The role of prey morphology and behaviour. Limnol. Oceanogr., 32: 167-177.

Received: January 2011

Accepted: March 2011 